\title{
Messages from the apocalypse \\ Security issues in American TV series
}

Stephen Stockwell ${ }^{*}$

School of Humanities, Griffith University, Gold Coast, Australia.

\begin{abstract}
While the Cold War generated a number of American TV series exploring national security issues in the context of apocalyptic nuclear policies, it was the end of the Cold War that raised issues about the purpose of the security services and saw television series from The $X$-Files with the recurring trope of security conspiracy leading to apocalypse. Since 9/11, terrorism, asymmetric warfare and the constant threat of apocalypse have been so inventively explored by American TV series that this paper argues they have led mainstream news services in the discussion of security issues. In particular 24 and West Wing scooped the mainstream press in discussion of the corrosive effect of state-sanctioned torture and assassination on the US presidency. The American TV series contribution to democratic deliberation is considered.
\end{abstract}

\section{Introduction}

\footnotetext{
*Email: s.stockwell@griffith.edu.au
} 
American television series are industrial products concerned predominantly with constructing audiences and selling them to advertisers. This has led to charges that producers seek “dumbed down” programs that appeal to broadest possible audience. However TV writers and producers since the 1960s have explored the complexities of national security to appeal to audiences across the political spectrum by playing off a deep-seated paranoia in American politics. TV has been a major component of American life for 60 years and has developed a symbiotic relationship with the national collective consciousness. Now a global market in television programs and formats has emerged that “appears to integrate television institutions into a trans-border, even perhaps worldwide, system of cultural business and finance.” (Moran 2009, 157) American television series are marketed and consumed around the world and have become key factors shaping global politics (Crothers 2007). Significant shifts in US politics (the Cold War, the end of the Cold War, 9/11, environmental emergency) are played out in TV fiction series in ways that allow writers and producers the opportunity to explore events in directions and to depths that news and current affairs cannot reach because of their commitment to objectivity balance and accuracy. As will be seen below, the best of journalism over the last decade, from esteemed investigators or citizens at the right place at the right time, have followed in the wake of TV series that have been first to tackle the big topics.

While the television series does face challenges as audiences migrate to the internet and gaming platforms, the industry is responding to emerging conditions with new economies not so dependent on broadcast audiences. For example, subscription cable is the source of many of the most interesting recent TV series and product 
placement has become a valuable source of income (Galician 2004). More significantly for this paper, boxed DVD sets with extras and commentary offer an entirely different kind of event to haphazard weekly viewing. There is greater audience control of the experience and the ability to come to a closer appreciation of the story arc, the broad, complex narrative flow, the subtleties of which can be lost in the vagaries of weekly viewing. A number of writers and critics have pointed out how the transition from serial to sprawling epic mimics the process where Charles Dickens and other $19^{\text {th }}$ century writers’ serial work became major novels. (Duffy 2008, 12, Bradley 2009, 5).

After establishing the parameters of the security/apocalypse nexus, this paper explores how a number of high profile American television series address national security issues in the context of the threat of apocalypse. After reviewing the heritage of American 60s Cold War television this paper considers, the loss of purpose in the security services after the Cold War and how The X-Files found deeper threats than anything the old Soviet Union had to offer. The paper then considers how TV producers/auteurs built on the success of that program to create a string of TV series that investigated complex political and philosophical issues that arose from security concerns as the US government faced the ever-present threat of apocalyptic annihilation, from terrorism before and after 9/11 and biological threats both natural and man-made. National security was explored explicitly in West Wing and 24 and there is evidence their investigation of the quicksand of presidential powers in a time of terror preceded the work of the mainstream news press. Finally the paper considers the impact of this discussion on the future of democratic deliberation. 


\section{Apocalypse and Security}

National security and the threat of apocalypse have been intimately entwined in United States politics since the strength of the Soviet Union nuclear and space programs became obvious in the 1950s. Security had always been a concern for both the United States and the Soviet Union, states that both emerged from civil wars with national security institutions to combat sabotage, infiltration and any attack that would threaten the integrity of their national territories (the Secret Service and Cheka respectively). With the construction of missile systems for inter-continental nuclear conflict, apocalyptic interference with national security became realistic possibility, as became abundantly clear during the 1962Cuban Missile crisis. During the 1960s there was a growing concern evident in American politics that the nation was under siege and a distinct fear, comprehensively sketched in the1962 movie, The Manchurian Candidate, that US Presidents were giving up national sovereignty to outside forces. The compromised presidency was just one notion addressed in the seminal essay, 'The Paranoid Style in American Politics’ which reviewed the long history conspiracy theory to appreciate its attraction to those outside the decision-making process and its debilitating effects:

proponents are only concerned with the "consequences of power ... and have no chance to observe its actual machinery” (Hofstadter 1964, 85-6). 
The parameters of national security after $9 / 11$ are made explicit in the mission statement of the US Homeland Security Department: "We will lead the unified national effort to secure America. We will prevent and deter terrorist attacks and protect against and respond to threats and hazards to the Nation. We will secure our national borders while welcoming lawful immigrants, visitors, and trade.” (Homeland Security 2008, 3) In a covering letter from the Secretary of Homeland Security, a preparedness for the nearapocalyptic is apparent in the commitment to "respond to major disasters and emergencies, including catastrophic events” (Homeland Security 2008, ii).

Now concerns about national security have expanded to incorporate a general concern with human security: “a comprehensive concept that rests on the four 'pillars' of military/strategic, economic, health-related and environmental security.” (Human Security Institute, 2010) Rapid population growth, radical shifts in global production patterns, new diseases and massive human intrusion into the natural environment have provided the potential for apocalyptic dysfunction across the full gamut of human activities. These many layers of national security are reformulated in individuals' lives as concerns for personal and domestic security that have been met with the development of new industries supplying martial arts training, bodyguards and home security. Security has become a matter of academic concern within the sub-fields of various disciplines of the social sciences and humanities including politics, international relations, criminology and sociology. It is clear, even from this broad overview, that there are diverse approaches to different forms of security: global, national, community, family, individual. 
The biggest conceptual threat to human security is apocalypse, no longer through nuclear competition with the Soviet Union but rather through a web of contributing possibilities - terrorist, asymmetrical, biological, economic, environmental, strategic, inadvertent. This shift has activated rather than assuaged the conspiracy theorist and Hofstader's observation is even more relevant today than it was in 1964: “The paranoid spokesman sees the fate of conspiracy in apocalyptic terms - he traffics in the birth and death of whole worlds, whole political orders, whole systems of human values.' (Hofstader 1964) While resort to the apocalypse as an explanatory mechanism is rightly seen as alarmist, human society has become so large, unwieldy and subject to unexpected consequences that a variety of phenomena could conceivably set of a string of events that lead to global catastrophe. The tenuous nature of the banking system revealed in September 2008 could have started a financial avalanche with consequences more dire than the Great Depression (Stiglitz 2010).

Apocalypticism is a biblical concept arising from Jewish and Christian writings around the time of Christ and crystalised in the Revelations of St John where he prophesied violent events leading to the end of the world. It is studied in eschatology, that branch of theology dealing with death, judgement, heaven and hell, and promoted by millennialism, politico-religious prophecies of the return of Christ (Revelations 20: 1-7). Millennial ideas flourished in Western Europe between the eleventh and sixteenth centuries (Cohn 1970, Daniel 2002). Apocalypse influenced seventeenth century thinkers including Newton, Milton and Cromwell and continues to inspire alternative religions 
across the world now (Weber 2000, 3-5). Particularly disturbing is the alliance between militant Israelis and Christian fundamentalist working towards rebuilding the Hebrew Temple in Jerusalem and thus bring on apocalyptic times (Krupey 1990, 286-98). Apocalyptic culture is alive in the United States where bizarre behaviours from making yourself a werewolf to cannibalism establishes how people are living at the end of days, at least in their own minds (Parfrey 1990).

To understand the attraction of TV series with story arcs through security issues to apocalypse, it is important to appreciate how everyday, mundane politics connects with the apocalyptic on a regular basis. George Bush Snr’s New World Order speech following the first Gulf War in 1991 aroused paranoia and fuelled incidents such as the Branch Davidian tragedy in Waco in 1993 and the Oklahoma City bombing in 1995. In anticipation of the arrival of the new millennium, the FBI's 1999 Megiddo report sketches the potential for domestic upheaval in the United States from racist uprisings to the Y2K bug (FBI 2002). Since 9/11 there are suggestions that apolitical conspiracy theories such as the supposed cover-up of UFOs and alien visitations are used to introduce potential adherents to hard-right conspiracy theories (Barkun 2003). Others argue from a leftist perspective that conspiracy theories play an important part in US democracy because they signal the need for more transparent government (Fenster 2008). Both Barkun and Fenster make useful contributions because discussion of conspiracy theory and apocalypse point to problems with secrecy and purpose in contemporary politics. 


\section{Apocalyptic Precursors}

Star Trek is emblematic of 1960s American television series have that toyed with security issues and threats of apocalypse. The science fiction series ran through 80 episodes from 1966 to 1969 and its opening credits famously promised "to explore strange new worlds, to seek out new life and new civilizations, to boldly go where no man has gone before.” The rhetoric reflects President John Kennedy’s support for the space program and the Peace Corps, both seemingly altruistic activities with benefits to national security. The new worlds encountered often proffer the possibility of utopia only for a dystopian or apocalyptic twist to threaten the security of the world, the crew or the universe. Then the intervention of the Star Trek crew, paragons of inter-racial harmony, liberal forbearance and ethical clarity, provide the inhabitants of other worlds with new paths to capitalist-inclined perfectibility (Schubert 1997, Barad and Robertson 2000). Dr Who (1963-89 plus 2005-presesnt) from the United Kingdom covers similar territory on an even cheaper budget (Tulloch and Alvarado 1983).

Other television series from the 60s that explored security issues with apocalyptic facets include a number of espionage series spinning off from the James Bond phenomena. American programs such as The Man from UNCLE (1964-8), I Spy (1965-8) and The Wild, Wild West (1965-9) brought a futuristic, sci-fi sensibility to the political thriller genre while exploring the practicalities of Cold war spycraft in the face of apocalyptic events. Feeding off the countercultural tempo of the times, these series 
explored the activities of security agencies: humans pushed to the extreme of their experience undergoing hypnosis, hallucinogenic experiences, identity shifts, mind alteration and dream modification. The CIA's mind control experiments utilizing such methods are now well documented (Richelson 2002; Streatfeild 2006). UK programs The Avengers (1961-9), The Prisoner (1968-9) and Callan (1967-72) covered similar territory, perhaps with more style (see for example Miller 1997).

While the 70s and 80s were not totally deficient of TV series with security elements (A-Team 1983-6, MacGyver 1985-92), nothing from American producers really competed with the intensity of the 60s product until The X-Files (1993-2002), a sci-fi series featuring two FBI agents exploring paranormal events and a long-running conspiracy at the heart of the American government and security services. Running for nine seasons, the parameters of the program were "fiction that takes place within the realm of extreme possibility” (Goldstein 1993). One FBI agent (Fox Mulder) is a grudging believer in the paranormal and government conspiracy while the other (Dana Scully) has a healthy scientific scepticism. This contrast sets off a lively debate about perception and proof, radical empiricism against the scientific method, government malfeasance versus the exigencies of governance that underlines the irony of the show' tagline: "The Truth Is Out There”. In the first season, stand-alone story-lines investigate paranormal activities in "monster of the week" episodes that raise security concerns: mind control; intentionality of artificial intelligence; the blurred line between humans and mutants. A few clues of alien presence blossom, by the second season, into a frantic effort to reveal a full-blown conspiracy to cover up government assistance for an alien 
take-over of the planet. After the Cold War, as security services looked for purpose, the message was clear: the next apocalypse could come from anywhere, particularly after Waco and Oklahoma, from within.

\section{The Impact of $9 / 11$}

$X$-Files raised the bar for American television series and found a deep audience interest in security issues. $X$-Files was almost finished its run before $9 / 11$ but the many programs it influenced took the opportunity to respond to 9/11 either explicitly or in new story lines or new attitudes from its characters. The monster of the week element of $X$ Files was reworked in a number of programs with super-natural themes: Buffy, the Vampire-Slayer (1997-2003) and Charmed (1998-2006) both featured young, postfeminist heroines in the midst of an security crisis of vampires, demons and an encroaching apocalypse from the underworld (on Buffy in particular see Kaveney 2004). After 9/11, the threats of take-over by dark forces become more insistent and these young women respond in Bush-Cheney style: adapting belief systems to fit the shifting world as new, threatening facts come to light. While there is much recrimination in season 3 (1999) when Faith accidentally kills a human (Richardson and Rabb 2007), the final season (2003) accepts collateral damage on the path to ultimate victory when Buffy's hometown Sunnydale is destroyed to avoid the apocalypse about to emerge from the Hellmouth beneath it. Similarly Charmed the battle between Whitelighters and Darklighters becomes more intense after 9/11 and, for example, season 7 in 2005 ended 
with a battle that sees the complete destruction of the sisters' house with many police and fire-fighters in peril. Most recently, Supernatural (2005-present) has filled the demon of the week slot with two brothers who battle intractable demons, and some angels, committed to creating apocalyptic hell on earth. As the apocalypse nears and Lucifer leads more demons from hell, angels have been sent to assist the brothers but God has absented Himself and groups of angels are at war with each other. Supernatural embraces moral complexity in ways that would have been unthinkable in the immediate aftermath of $9 / 11$.

$X$-Files revitalization of science fiction left the ground open to a resurgence of space opera. The most sprawling military sci fi series since Star Trek itself is Stargate SG1 (1997-2007) where the limits of human intentionality are explored in an alien universe where torture, apocalypse and human extinction are constant threats. The show may be read as supportive of the military machine on the ground in Iraq and Afghanistan while at the same time offering a striking critique of these interventions. Firefly (2002) is a sci fi western that follows a space captain and crew seeking to maintain their independence against a strongly centralized security state. It was perhaps the first Hollywood product to raise issues of the dangers of excessive executive power after 9/11. Battlestar Galactica (new series 2003-9) is a space opera with a post 9/11 twist: after an apocalypse of robot revenge, the eponymous military spaceship attracts a fleet of ships that contain most human survivors who then attempt to reform a democratic government. The story line confronts complex security issues such as the limits of governance in times 
of warfare, the breadth of presidential prerogative and the utility and acceptability of torture.

\section{Presidential Power, Torture and Assassination}

The confrontation with contemporary security issues in the series discussed above is much more explicit in two American television series that pick up $X$-Files' preoccupation with the inner workings of the Washington DC and move off in much more realistic directions. The presidential politics represented in West Wing (1999-2006) and 24 (2001-2010) reveal a hotbed of ethical indecision that rests in the constitutional vagueness about the powers of the president to ensure the security of the United States. Past presidents have been chastised by the Supreme Court for abuse of presidential war and foreign policy powers including Jefferson who ordered troops into battle without Congressional approval and Lincoln who suspended habeas corpus during the Civil War (Shapiro, Kumar and Jacobs 2000). While Congress limited the president’s powers after Vietnam and Watergate, those powers were widened after 9/11 by the Patriot Act and other legislation that gave the President broad authority to take executive action (Rozell 2002).

West Wing follows the fictional presidency of Josiah Bartlett (Rollins and O'Connor 2003). The first two seasons (1999-2001) are set in the first term of the Bartlett administration and portray the humanity of the president and his staff as they pursue a 
lift-liberal agenda. Security practicalities are discussed in the context of an assassination attempt by a home-grown racist group aimed not at the president but at his black aide. The third season (2001-2) was scheduled to begin within a month of the attacks on the World Trade Centre and rather than return immediately to the regular storyline, the producers ran a special on terrorism, Isaac and Ishmael. That program was a balanced rehearsal of issues pertinent to terrorism and security to a group of students caught in the White House during a security lockdown by a range of cast members. Questions of Islamic fundamentalism became more prominent in the series’ story arc from that time on: in season three, episode four an international crisis erupts when Palestinian terrorists kill two Americans in Israel; in episode eight, The Women of Qumar, the renewal of a lease on a Middle East military base goes ahead despite that nation's treatment of women; in episode 13 the Communications Director writes an inflammatory speech condemning Islamic extremism for the president to deliver at the $\mathrm{UN}$; in episode nineteen a group of schoolgirls in Saudi Arabia are prevented from escaping a burning building by religious police because they were not dressed according to Sharia law; and the last three episodes of the season (20-22) contain a significant story arc when a terrorist threat is made against San Francisco's Golden Gate bridge and the mastermind visits the United States with diplomatic immunity. The president orders the extra-judicial death of the Middle East player at the end of season 3 . The president's uncertainty about his actions and a journalist's dogged pursuit of the story are recurring themes in season 4 (2002-3).

24 began going to air less than two months after 9/11. It uses reality TV conventions of real-time plot, split screen exposition, unexpected interventions and a 
close focus on personal emotions to explore the interactions between a number of fictional US presidents and the Counter Terrorism Unit. The series centres on CTU officer, Jack Bauer, a highly proficient agent with few moral scruples when he judges that the ends justify the means. Story-lines are powered by the multiple apocalyptic threats: nuclear, biological, chemical and cyber attacks, terrorist plots, presidential assassinations and conspiracies around government and corporate corruption. Jack Bauer does not hesitate to torture, behead or otherwise kill enemies, bystanders and even colleagues for operational purposes and the president takes only a little longer to order the torture of a recalcitrant member of his own staff. There is one very clear reading of this series as a justification for torture, extra-judicial murder and an absence of oversight or control on security services. Others are concerned with the "profound lie" that torturers can retain their humanity if the cause is just and question whether the purpose of the revelation is to normalize this behaviour (Zizek 2006). One alternative to both those viewpoints is that this series revealed, albeit fictionally, a massive shift in ethical thinking, and action, by the US government in the aftermath of $9 / 11$ and those revelations came via TV series long before they came through the mainstream news media.

This is not to discount the excellent work by 60 Minutes and the New Yorker's Seymour Hersh in revealing the torture in Abu Ghraib, cross-border rendition to facilitate torture and the Joint Special Operation Command assassination squads and how responsibility for those excesses went back to the cabinet and the presidency. However it must be said that this traditional news work came almost two years after these issues 
were first discussed in a fictional context. A timeline of news events and fictional developments are laid out in Table 1.

Table 1. Discussion of torture in US drama and news programs after 9/11

\begin{tabular}{|c|c|c|}
\hline Date & News Event & Fictional Development \\
\hline 11 Sept 01 & Al-Qaeda attacks NY \& DC & \\
\hline 3 Oct 01 & & $\begin{array}{l}\text { West Wing Special on terrorism - } \\
\text { Isaac and Ishmael }\end{array}$ \\
\hline 6 Nov 01 & & First episode of 24 goes to air \\
\hline 28 Nov 01 & & $\begin{array}{l}\text { WW Women of Qumar on US bases } \\
\text { (cf Saudi Arabia) }\end{array}$ \\
\hline 2 Dec 01 & & 24 Bauer threatens torture \\
\hline 22 May 02 & & $\begin{array}{l}\text { WW President orders diplomat's } \\
\text { assassination }\end{array}$ \\
\hline 22 Sept 02 & & $\begin{array}{l}\text { Second season of } 24 \text { begins with } \\
\text { torture by } 3^{\text {rd }} \text { parties and decapitation } \\
\text { by Bauer }\end{array}$ \\
\hline 25 Sep 02 & & $\begin{array}{l}W W \text { Bartlett rationalizes assassination } \\
\text { order }\end{array}$ \\
\hline 11 Dec 02 & & $\begin{array}{l}\text { WW Assassination on president’s } \\
\text { conscience }\end{array}$ \\
\hline $4 \mathrm{Feb} 03$ & & $\begin{array}{l}24 \text { President orders info extraction } \\
\text { from staff member by ‘any means } \\
\text { necessary’ }\end{array}$ \\
\hline 11 Feb 03 & & $\begin{array}{l}24 \text { President notes 'everyone breaks } \\
\text { eventually' }\end{array}$ \\
\hline 6 Mar 2003 & $\begin{array}{l}\text { USA Today "Interrogation is tough } \\
\text { but not torture" }\end{array}$ & \\
\hline 20 Mar 03 & Invasion of Iraq & \\
\hline 16 Jan 04 & $\begin{array}{l}\text { US Command begins Abu Ghraib } \\
\text { investigation }\end{array}$ & \\
\hline 28 Apr 04 & $\begin{array}{l}\text { 60 Minutes does story on Abu } \\
\text { Ghraib }\end{array}$ & \\
\hline 10 May 04 & $\begin{array}{l}\text { New Yorker Seymour Hersh story } \\
\text { on chain of command re Abu } \\
\text { Ghraib blames President }\end{array}$ & \\
\hline 12 May 04 & Abu Ghraib screening at Pentagon & \\
\hline 23 Oct 04 & Envoy silenced re rendition & \\
\hline 14 Feb 05 & $\begin{array}{l}\text { New Yorker covers outsourcing } \\
\text { torture }\end{array}$ & \\
\hline 31 Mar 09 & $\begin{array}{l}\text { Hersh and Goodman discuss JSOC } \\
\text { assassination wing }\end{array}$ & \\
\hline
\end{tabular}


Further, a search for "terror" and "torture” in a US newspaper database shows that the first hit with reference to 9/11 do not come until after the March 2003 capture of Al Qaeda mastermind, Khalid Shaikh Mohammed and then only to provide assurance that he would not be tortured. Subsequently The Times revealed on April 202009 that he had been "waterboarded" so he thought he was drowning 183 times.

Discussion of the fluid limits to the president's powers and the fuzzy points of his transition from national security into illegality points to a number of American television series that explore criminality from the offenders’ points of view: The Sopranos (19992007), The Wire (2002-8), Weeds (2005-present) and Dexter (2006-present). Each of these programs have narrative points that refer directly to security issues arising out of 9/11 but of greater interest here is consideration of the ethical play engaged in by key characters (Tony Soprano, Omar Little, Nancy Botwin and Dexter Morgan) as they balance the security of their families and friends against the necessity of fitting their conduct within the flexible rules of their particular criminal milieus. Each of these characters is exploring the president's dilemma of maintaining security within the flexible framework of his powers against opponents with their own rules.

\section{The Future of Democratic Deliberation}

Given the evidence above that supposedly dumbed down American television series have provided greater and more timely opportunities for the productive 
consideration of the excessive use of presidential powers by the security services than the mainstream news media, it is interesting to consider the future of discussion, debate and deliberation in emerging democratic formations. While the media retains its responsibilities as the fourth estate holding executive, judicial and representative arms of democracy to account, the compromises required by news-gathering processes, commercial imperatives and the increasing power of the state has led to the deflation of the public sphere (Habermas 1989) and the increasing manufacture of consent (Herman \& Chomsky 1988). But this is not new. It has always been difficult to pursue the responsibilities of the fourth estate against the interests of owners, advertisers and government but since the invention of the daily press, media workers have always found ways to use fractures within and between corporations and governments to create the space to connect to audiences.

The TV series provides interesting opportunities to enhance the quality of deliberation not only by the utilization of characterization to portray the humanity of political players and citizens generally, but also using narrative structure to delve into the complexity of the many different sides to a debate and their various consequences to a range of individuals. The West Wing, for example, can discuss an issue with more depth and greater detail than news programs constrained by time limits to news stories, adversarial structures for the discussion of current affairs and a binary mindset that allows only two sides to a story (Beavers 2003). Others would argue specifically that West Wing was a 'subversive competitor' to the growing cynicism among citizens about politics manufactured by the media (Miller 2000). 
The emerging bio-politics offers new challenges to the media. Climate change has already thrown up new security concerns as weather events become more damaging more frequently and more complex crises sap government resources and community strength so the threat of apocalypse hinted at in the flooding New Orleans and Pakistan becomes more common. Further, technological and scientific change is occurring so rapidly that what would have once been minor problems can compound to create major dysfuction: genetic, micro and nano technologies open the possibility that changes at the molecular or even sub-atomic levels can have social or global impacts. The complexity and speed of new scientific development requires a new form of bio-politics not just to manage the situation, but to avoid catastrophe. These are areas that the news media only covers haphazardly and when problems are already well out of control.

Lost (2004-10) and Heroes (2006-2010) are TV series that have already addressed such issues. Lost follows the fate of survivors after their plane crashes on an island which has been the site of extended scientific experimentation that raises a number of complex questions the individual, their community and the globe (Kaye 2007). This experimentation has been carried out by the fictional Dharma Initiative, a project that began in 1970 when two doctoral candidates from the University of Michigan seek funds from a corporation to build large research facility on a secret island where scientists could research meteorology, psychology, parapsychology, zoology, electromagnetism and social planning. By the new millennium many of these experiments are running out of control creating major biological and geo-thermal security threats to the island and the world. Specifically, while the island can cure pre-existing health complaints, it also 
harbours a sickness that can eradicate large human populations. Heroes explores how human evolutionary mutations come to terms with their strange capabilities as they steer a path between the industrial corporations that want to capture them to manage the evolutionary process and their own complicity in the most apocalyptic outcomes of home-grown terrorism.

Both Lost and Heroes address contemporary security issues in ways that challenge mainstream politics: Lost has a sympathetic portrayal of a member of the Iraqi Republican Guard, Heroes explores manipulation for nefarious purposes at the highest level of congressional and presidential politics. However, it is the attention they bring to growing issues of biosecurity that are of particular interest in this paper. At the most mundane level biosecurity addresses issues such as transmission of infectious diseases, quarantined pests, invasive alien species, living modified organisms and biological weapons but it can go much further to manage all disruptions to the environment, not only those that are human products but also those that are natural responses to developing conditions. While some of these issues such as climate change have caught the attention of mainstream politics, other concerns about genetic manipulation, cloning, out of control biological experiments, unintended consequences of cosmetic surgery and other forms of transhuman adaptation, environmental contamination from radiation, chemicals and viruses are still only of marginal interest and their security implications are rarely commented upon. Further both Lost and Heroes provide the opportunity for exploration of how projects of ameliorisation so quickly descend into dysfunction that threatens human security. While traditional news media have trouble dealing with the speed and 
complexity of bio-politics, these TV series recognize the contemporary integration of science, business and politics which goes a long way to explaining the intractability of bio-political problems - environmental, health-related and genetic. These programs already assume the Gaia-thesis of a whole-world system where the butterfly effect is in full force - a small chance at one point produces massive change somewhere else - and those massive, unintended and unpredictable changes are the greatest emerging apocalyptic threats to human security on a planetary basis. These events are so large, complex and different that perhaps fictional narratives are the only means for to reach significant audiences and stimulate them to discussion and deliberation.

So where has the critical voice on security issues in American television series come from and how might it be sustained? Further what does it reveal about shifts in media, deliberation and world politics? The war on terror, the force of Bush's neoliberalism and the Obama administration inability to move beyond confrontation in Afghanistan and Iran provides one set of explanations for a radical response than is not so much anti-war but questioning of the US military's ability to conclude wars in a meaningful way. As American TV series are more often consumed via DVD and internet download, the broadcast paradigm is losing its power and these audiences shifting from platform to platform are led by an avowedly liberal wedge of consumers who are open to complex critiques of government policy and are keen to explore security issues. They appreciate the links between conspiracy theory and investigative journalism2008, xii, Stockwell 2005). Also the production economics of American TV series are based around long but tightly constructed story arcs that require auteur/script writers to produce 
intriguing but cohesive narrative trajectories and the American empire and its security apparatus is one topic large enough to anchor such stories while the threat of apocalyse is always a useful means to sustain audience interest. These political, technological and production rationales for the growing interest in security matters, point to a shared interest between the audience and the writers, actors and producers in the way security issues impact on the politics and life opportunities in a country that still prides itself on being the prototypical democracy dependent on robust and widespread debate.

As the broadcast paradigm is undercut by the profusion of channels and the rule of the internet, the news media are in deep trouble as they fail to communicate their purpose. American television series have taken the opportunity to address this gap by probing the conundrums that threats of apocalypse and the heightened security state throw up. Via convergent technologies capable of instantaneous communication with a global audience, US television series will continue to be simultaneously an institutional force, a viable art form, a social catalyst and a reflection of the American mind at work (Edgerton 2004). This situation will not remain stable for long. Broadcast journalism is less than a century old and has been rightly criticized for putting too much power in the hands of too few owners, editors, anchors and correspondents. Just as the security services concentrating on the big picture failed to see the micro events that culminated in 9/11, broadcast journalism is sidelined by the micro discussions between the audience and the creators of TV series on chat sites, Facebook and Twitter. Already, participants are making use of massive multi-player online games to further open up the possibilities for deliberation with the technologies at hand. While there is much to be concerned about 
as traditional forms of deliberation face in significance, there is also much hope in the willingness of citizens to carry on discussion and debate any way they can.

\section{Bibliography}

Barad, Judith, and Ed Robertson. 2000. The ethics of Star Trek. New York: Harper Collins.

Barkun, Michael. 2003. A culture of conspiracy. Berkeley: University of California Press.

Beavers, Staci L. 2002. The West Wing as a pedagogical tool. PS: Political Science \& Politics 35: 213-6.

Bradley, James. 2009. The idiot box grows a brain. The Australian Literary Review. February 4.

Cohn, Norman. 1970. The pursuit of the millennium. New York: Oxford University Press.

Crothers, Lane. 2007. Globalization and American popular culture. Lanham: Rowman \& Littlefield Publishers. 
Daniel, Randolph E. 2002. Medieval apocalypticism, millennialism and violence. Terrorism and Political Violence. 14, no. 1: 275-300.

Duffy, Michael. 2008. Television’s serial defenders. Sydney Morning Herald, December 6-7, Spectrum section.

Edgerton, Gary. 2009. The Columbia history of American television. New York: Columbia University Press.

FBI. 2002. Project Megiddo. Terrorism and Political Violence 14, no. 1: 25-52

Fenster, Mark. 2008. Conspiracy theories. 2nd ed. Minneapolis: University of Minnesota Press.

Galician, Mary-Lou, ed. 2004. Handbook of product placement in the mass media. New York: Routledge

Goldstein, T.J. 1993. Within the realm of extreme possibility. Cyberspace Vanguard Magazine. http://www.skepticfiles.org/skeptic/x-filesj.htm

Habermas, Jurgen. 1989. The Structural Transformation of the Public Sphere. Cambridge: Polity Press. 
Herman, Edward and Noam Chomsky. 1988. Manufacturing Consent. New York: Pantheon.

Hofstadter, Richard. 1964. The paranoid style in American politics. Harper's Magazine, November, 77-86.

Homeland Security Department. 2008. Strategic plan: One team, one mission, securing our homeland. Washington: Homeland Security Department.

Human Security Institute. 2010. Working toward a secure and sustainable future for humanity. http://blogs.unbc.ca/his.

Kaye, Sharon, ed. 2007. Lost and philosophy. Malden: Wiley-Blackwell.

Kaveney, Roz, ed. 2004. Reading the Vampire Slayer. London: Tauris Parke.

Krupey, Gregory. 1990. The Christian right, Zionism and the coming Penteholocaust. In Apocalypse Culture: Revised and Expanded, ed. Adam Parfrey, 28698. New York: Amok Press

Miller, Matthew. 2000. The Real White House. Brill's Content. March. Reprinted at http://b4a.healthyinterest.net/news/archives/2000/03/the_real_white.html. 
Miller, Toby. 1997. The Avengers. London: BFI Publishing.

Moran, Albert. 2009. New Flows in Global TV. Bristol: Intellect.

Parfrey, Adam, ed. 1990. Apocalypse Culture: Revised and Expanded. New York: Amok Press.

Richardson, J. Michael and J. Douglas Rabb. 2007. Buffy, faith and bad faith. Slayage 23. http://slayageonline.com/essays/slayage23/Richardson_Rabb.htm.

Richelson, Jeffrey T. 2002. The Wizards of Langley. Boulder: Westview Press.

Rollins, Peter C. and John E O'Connor. 2003. The West Wing: the American presidency as television drama. Syracuse: Syracuse University Press.

Rozell, Mark. J. ed. 2002. Executive Privilege: Presidential Power, Secrecy and Accountability. 2nd ed. Lawrence: University Press of Kansas.

Schubert, Kurt D. 1997. Assimilating the final frontier. BA Hons diss. Griffith University.

Stiglitz, Joseph. 2010. Free Markets and the Sinking of the Global Economy. London: Allen Lane. 
Stockwell, Stephen. 2005. Beyond Conspiracy Theory. Paper presented at Journalism Education Conference, November 29-December 2, in Surfer's Paradise, Australia.

Streatfeild, Dominic. 2006. Brainwash. London: Hodder \& Stoughton.

Tulloch, John and Manuel Alvarado. 1983. Doctor Who: The Unfolding Text. London: Macmillan.

Weber, Eugen. 2000. Apocalypses: Prophecies, cults, and millennial beliefs. Cambridge: Harvard University Press.

Zizek, Slavoj. 2006. The depraved heroes of 24 are the Himmlers of Hollywood. Guardian, January 10. 